\title{
PENGARUH UKURAN ATOMISASI BAHAN BAKAR TERHADAP UNJUK KERJA MOTOR BAKAR
}

\author{
Abrar Riza, Hansel dan Harto Tanujaya \\ Jurusan Teknik Mesin Fakultas Teknik Universitas Tarumanagara \\ Jl. Letjen. S. Parman No. 1 Jakarta 11440 \\ e-mail: abrarr@ft.untar.ac.id
}

\begin{abstract}
The size of droplet affects the evaporation of the fuel. The greater the size of droplet is also the energy of fuel evaporation. The evaporation energy is directly proportional to the size of the droplet and oxidation must be mixed homogeneously. Mixing conditions in the combustion process affect the rate of combustion. One of the conditions of combustion is the droplet to the vapor. The more perfect the evaporation process the better the combustion process. This study saw the success of combustion due to the size of droplet on the performance. The droplet produced by atomization in the form of liquid granules. The size of atomization is the determinant of burning success. The four-stroke Otto engine performance depends on the size of the atomization in order to mix well with the oxidant during combustion process. The results of the research characteristic of the machine are due to the influence of the size of the droplet seen from the generated power, torque and thermal efficiency. Characteristic features increase with decreasing the size of the droplet. Torque increased $7.9 \%$, power generated increased 7\%, and thermal efficiency increased up to 7.3\%. The results of this study show size of the droplet can improve the performance of engine.
\end{abstract}

Keywords: Droplet, vaporization and combustion

\section{PENDAHULUAN}

Pengkabutan bahan bakar menjadikan kelompok besar bahan bakar cair menjadi atomisasi dan pengkabutan dengan mendisribusikan partikel cair dikendalikan oleh nosel dalam ruang bakar. Fluks massa atomisasi memberikan informasi kemampuan penguapan didalam ruang bakar dengan asumsi semua partikel memiliki dimensi sama setiap ukuran nosel yang sama dan saat kecepatan putaran mesin sama. Hal ini penting karena ukuran partikel fungsi dari jarak antara partikel atom tersebut. Jarak antara partikel diperlukan sebagai celah udara panas memberikan panas ke permukaan setiap atomisasi untuk dapat mengalami proses penguapan. Sering juga terjadi sesama atomisasi saling bertabrakan dalam aliran turbulen dalam ruang bakar [1].

Keberhasilan pembakaran dalam ruang bakar dipengaruhi oleh ukuran pengkabutan bahan bakar cair sehingga proses atomisasi sangat berperan. Ukuran pengkabutan sangat bergantung pada diameter nosel. Penelitian ini memvariabelkan ukuran diameter nosel. Dipilih tiga ukuran nosel untuk dilihat efeknya terhadap keberhasilan pembakaran. Produksi atomisasi dalam pengkabutan yang baik ditentukan oleh ukuran diameter nosel [1]. Nosel ini berfungsi memecah bahan bakar menjadi partikel fluida disamping faktor viskositas dari bahan bakar. Perubahan viskositas setiap pengambilan data diasumsikan sama sehingga faktor viskositas tidak dibahas dalam penelitian ini.

Laju pembakaran dipengaruhi oleh koefisien penguapan dari sebuah butir (single droplet) hasil pengkabutan. Temperatur yang melewati sebuah droplet dianggap merata. Asumsi ini untuk mendapatkan satu nilai termal konduktivitas. Proses penguapan droplet dikendalikan oleh temperatur didalam ruang bakar. Proses penguapan droplet ini dipengaruhi oleh ukuran droplet, massa jenis bahan bakar dan konduktifitas termal [2]. Pada penelitian ini dibatasi pada faktor ukuran droplet karena berhubungan langsung dengan torsi dan daya mesin.

Pengecilan diameter nosel akan meningkatkan kecepatan yang dapat mempengaruhi bilangan Reynold sehingga memberikan efek turbulensi. Efek turbulensi memberikan efek swirl sehingga proses perpindahan panas antara udara panas dan partkel bahan bakar dalam ruang bakar semakin baik. Dalam kajian analitis, swirl atomisasi merupakan berbanding lurus dengan volume silinder piston dan berbanding terbalik dengan diameter nosel [3]. Viskositas dan tegangan permukaan serta laju aliran bahan bakar berbanding lurus dengan diameter atomisasi tetapi berbanding terbalik dengan tekanan dan kerapatan [4]. 
Penelitian ini mengkaji efek ukuran pengkabutan terhadap unjuk kerja mesin Otto empat langkah satu silinder. Variabel ukuran pengkabutan dilakukan dengan memvariasikan diameter nosel pengkabutan. Karakteristik variasi diameter nosel dilihat dari torsi, daya mesin dan effisiensi termal yang dihasilkan.

\section{METODE PENELITIAN}

Penelitian ini dilakukan dengan memvariabelkan putaran mesin tetapi beban kerja tetap. Putaran mesin divariasikan dari 6.000 rpm sampai dengan $12.000 \mathrm{rpm}$. Putaran mesin divariasikan setiap $500 \mathrm{rpm}$. Adapun variabel yang ditinjau dengan tiga buah ukuran nosel pengkabutan. Tiga nosel itu adalah main jet standar, lebih kecil dari main jet standar dan lebih besar dari main jet standar.

Boiling point dari droplet dipengaruhi oleh temperatur ruang bakar, luas kontak droplet dengan lingkungan dan temperatur permukaan droplet. Vaporisasi droplet merupakan driving force dari proses pembakaran. Boiling point merupakan fungsi dari massa jenis droplet dan diameter nosel serta jarak ke titik api terdekat. Adapun data yang didapat dari eksperimen adalah laju bahan bakar, putan mesin, torsi dan daya mesin yang dihasilkan serta AFR (air fuel ratio). Pengujian dilakukan dengan dyno-test. Setiap main jet (nosel) dilakukan tahapan pengujian yang sama.

\section{HASIL DAN PEMBAHASAN}

Hasil percobaan dapat menguatkan hipotesis bahwa ukuran pengkabutan dapat mempengaruhi proses pembakaran dalam ruang bakar. Urutan pembakaran yaitu pengkabutan bahan bakar setelah itu penguapan hasil pengkabutan tersebut disebut juga atomisasi. Panas sumber penguapan disuplai udara panas dinding silinder dalam ruang bakar. Setelah partikel teruapkan maka uap bahan bakar dapat bercampur secara homogenius dengan udara sebagai oksidator. Pencampuran bahan bakar dan udara dalam satu fasa ini diikuti penyalaan busi saat mendekati TMA, penyalaan busi mendorong penyalaan bahan bakar.

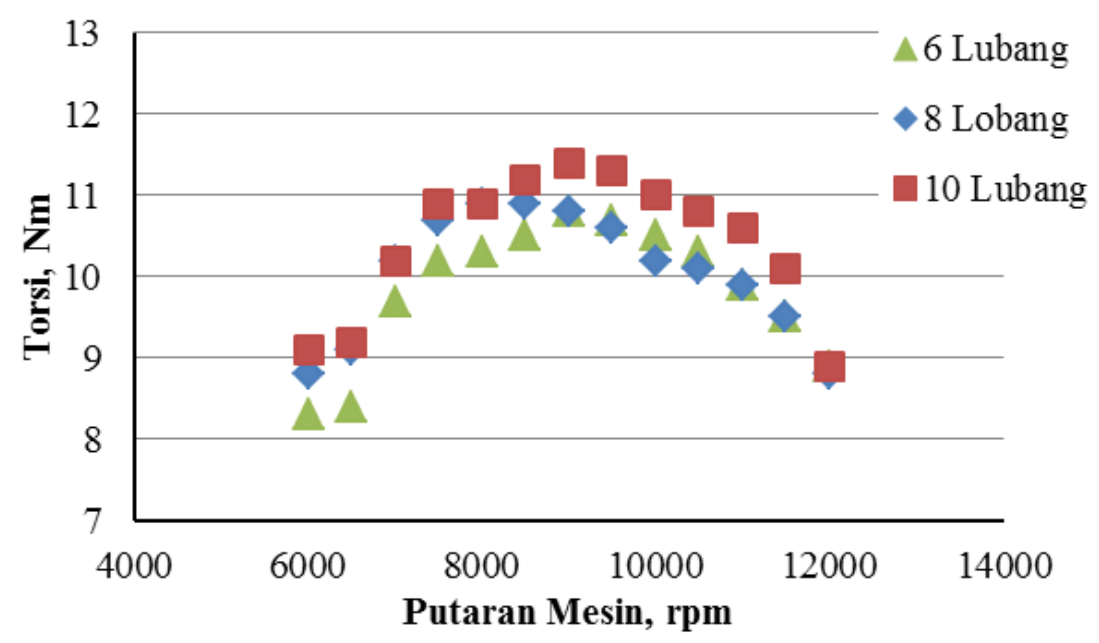

Gambar 1. Torsi terhadap putaran mesin

Gambar 1 dapat melihatkan tiga kurva yang mengacu pada pengaruh ukuran nosel. Kurva berturut-turut hasil dari menggunakan ukuran nosel standar, ukuran nosel lebih kecil dan ukuran nosel lebih besar serta ketiga nosel ini diasumsikan memiliki total luas lubang yang sama. Ukuran lubang nosel di hipotesis berbanding lurus dengan ukuran pengkabutan. Pengaruh besar pengabutan. Ketiga kurva diperlihatkan pengaruh ukuran pengabutan kentara terlihat setelah tercapai kecepatan pada kondisi torsi maksimum. Torsi yang dihasilkan oleh nosel dengan diameter lubang lebih kecil menghasilkan torsi lebih besar serta analisis tidak membahas kinetik pembakaran. 


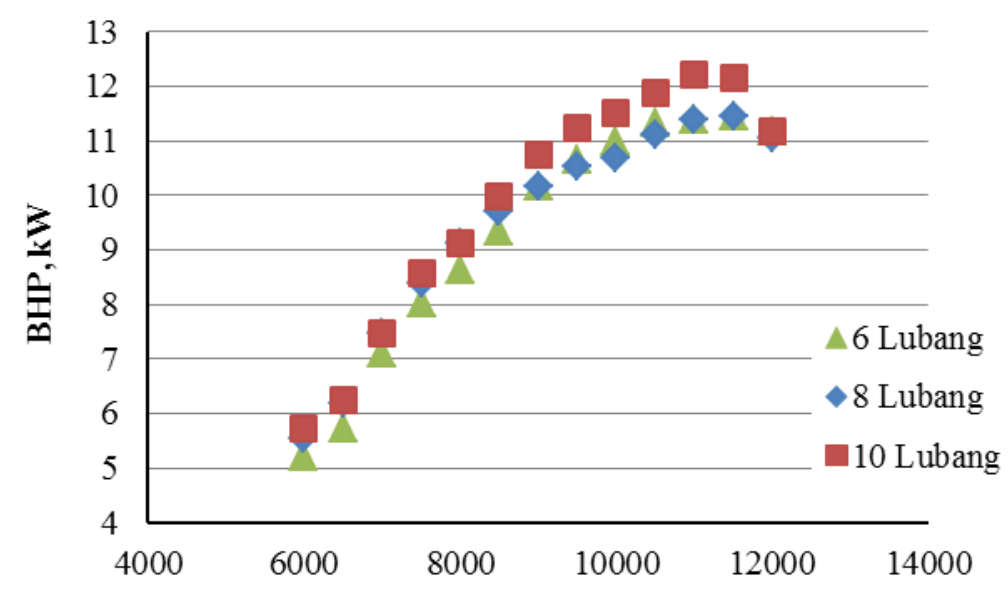

Putaran Mesin, rpm

Gambar 2. BHP terhadap putaran mesin

Konsep motor bakar menyatakan bahwa setelah tercapai kurva torsi maksimum maka kurva torsi mulai menurun. Padahal kendaraan bermotor membutuhkan kondisi kerja dengan daya yang dapat terus naik. Daya berbanding lurus dengan torsi, lihat Gambar 2. Untuk mengantisipasi kondisi ini, setelah tercapai torsi maksimum maka laju bahan bakar ditingkatkan sebagai kompensasi tenaga. Peningkatan laju bahan bakar diduga berefek pada laju penguapan. Ketika peningkatan laju bahan bakar proses penguapan kurang berjalan dengan baik sehingga ada peningkatan bahan bakar yang tidak berhasil terbakar.

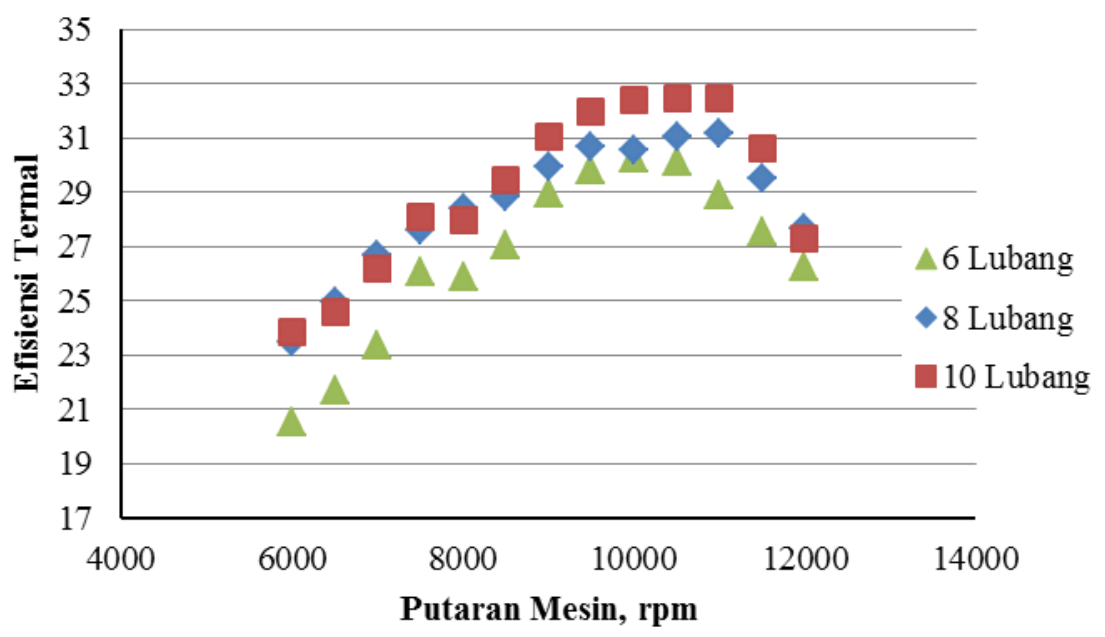

Gambar 3. Efisiensi termal terhadap putaran mesin

Ketika atomisasi hasil pengkabutan lebih besar ukurannya maka lebih sedikit bahan bakar yang berhasil terbakar sehingga lebih banyak bahan bakar sisa yang tidak terbakar. Bahan bakar sisa ini berubah bentuk menjadi gas-gas yang masih flammable seperti $\mathrm{CO}, \mathrm{H} 2$ dan beberapa bentuk hidrokarbon.

Efisiensi untuk nosel berdiameter lebih kecil terlihat lebih tinggi terutama setelah tercapai kondisi torsi maksimum. Efisiensi mengunakan nosel berdiameter lebih kecil terlihat lebih tinggi, dapat dikatakan bahwa sekitar torsi maksimum menjadi daerah ekonomis. Hal ini dikuatkan pada kurva bsfc dengan putaran mesin. Pada kondisi ini juga terlihat kurva untuk nosel lebih kecil memiliki kurva bsfc terhadap putaran mesin berada paling bawah.

Ketika laju bahan bakar meningkat maka kebutuhan energi untuk menguapkan atomisasi diruang bakar juga meningkat. Sementara itu kebutuhan energi yang tersedia relatif konstan akibatnya ketika atomisasi berukuran lebih besar dapat diduga keberhasilan penguapan lebih 
rendah. Kondisi ini jika dikaitkan dengan proses pembakaran sulit terjadi pencampuran yang homogen. Pencampuran yang kurang homogen ini berakibat proses pembakaran berjalan kurang baik dan bahan bakar sisa meningkat jumlahnya.

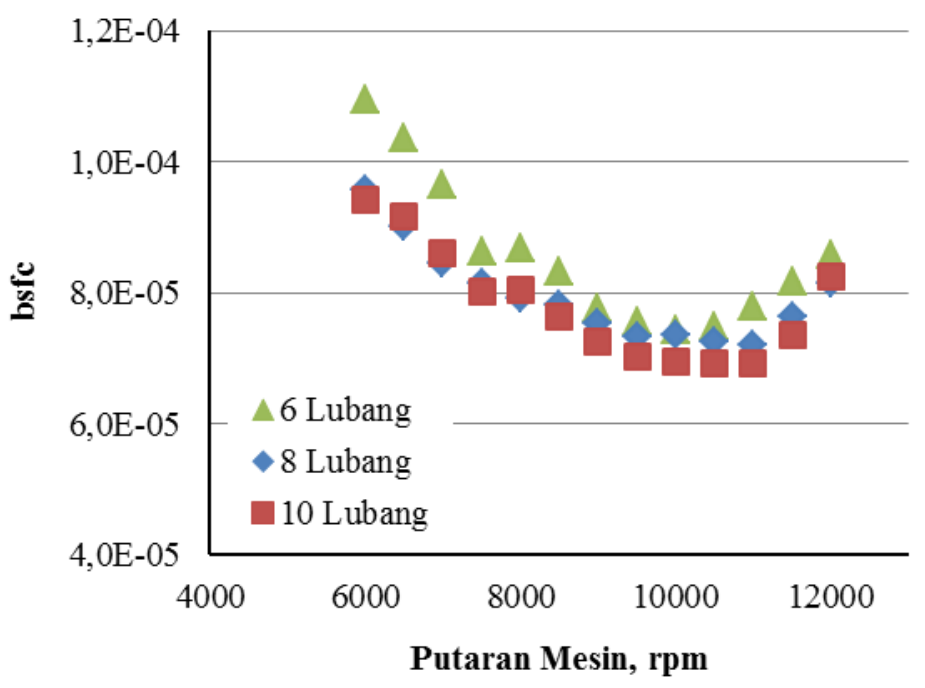

Gambar 4. BSFC terhadap putaran mesin

Keberhasilan terbakarnya bahan bakar bergantung pada ukuran atomisasi hasil dari pengkabutan yang dikaitkan dengan proses fisika dan proses kimia. Vaporisasi droplet mengontrol laju difusi molekular yang menjadi faktor penentu kimia kinetik [1].

\section{SIMPULAN}

Karakteristik mesin dipengaruhi oleh besaran ukuran pengkabutan/droplet yang dapat dikuantitatifkan dengan melihat daya dihasilkan, torsi dan efisiensi termal. Besaran karakteristik meningkat dengan menurunnya ukuran atomisasi hasil pengkabutan. Torsi meningkat 7,9\%, daya dihasilkan meningkat 7\%, dan efisiensi termal meningkat sampai 7,3\%. Hasil penelitian ini memperlihatkan ukuran atomisasi pengkabutan/droplet dapat memperbaiki karakteristik motor bakar dengan memasang nosel berukuran lebih kecil.

\section{DAFTAR PUSTAKA}

[1]. Williams, Alan, 1990, Combustion of Liquid Fuel Sprays, Butterworth and Co Ltd, Leed, UK.

[2]. Grassman, Irvin, Combustion, Elsevier, fourth edition, USA.

[3]. Chambel, A., Thermodynamic Analysis of Combustion Engine, Jon Wiley and Son Co, Canada.

[4]. Lefebvre, A.H., 1989, Atomization and Sprays, Hemisphere Publishing Co, New York. 